\title{
Management of Whiteflies, Whitefly-Vectored Plant Virus, and Insecticide Resistance for Vegetable Production in Southern Florida ${ }^{1}$
}

David J. Schuster, Philip A. Stansly, Jane. E. Polston, Phyllis R. Gilreath and Eugene McAvoy ${ }^{2}$

Continuing outbreaks of Tomato yellow leaf curl virus (TYLCV) in southern Florida emphasize that the vector of the virus, biotype $\mathrm{B}$ of the sweetpotato whitefly (SPWF), Bemisia tabaci (Gennadius) (also known as the silverleaf whitefly, $B$. argentifolii Bellows \& Perring), remains the key insect pest of tomatoes in Southern Florida. Growers rely heavily on insecticidal programs to combat the whiteflies and subsequent virus outbreaks. Transplants in the production house are drenched with the neonicotinoid imidacloprid (numerous suppliers) about a week prior to planting. Soil applications of neonicotinoids including imidacloprid, Platinum ${ }^{\circledR}$ (thiamethoxam; Syngenta Crop Protection, Inc., Greensboro, NC) or Venom ${ }^{\circledR}$ (dinotefuran; Valent U.S.A. Corp., Walnut Creek, CA) are made at or shortly after transplanting in the field. Most growers refrain from making foliar applications of neonicotinoids including imidacloprid, Assail ${ }^{\circledR}$ (acetamiprid; Cerexagri, Inc., King of Prussia, PA) or Venom after nymphal control with soil-applied neonicotinoids decline, because this practice could encourage the development of resistance to the neonicotinoid insecticides (Elbert and Nauen 2000). Insecticides in other chemical classes are applied foliarly to control SPWF adults and nymphs and include Fulfill ${ }^{\circledR}$ (pymetrozene; Syngenta Crop Protection, Inc., Greensboro, NC), Monitor ${ }^{\circledR}$ (methamidophos; Valent U.S.A. Corporation, Walnut Creek, CA), malathion (numerous suppliers), pyrethroids (numerous products and suppliers), endosulfan (several suppliers), Knack® (pyriproxyfen; Valent U.S.A. Corporation, Walnut Creek, CA), Courier® (buprofezin; Nichino American, Inc., Wilmington, DE) soap and oil.

A resistance monitoring program for the neonicotinoids in southern Florida has demonstrated that tolerance in biotype $\mathrm{B}$ has increased 8 fold on the average from 2000 to 2006 for imidacloprid and about 15 fold from 2003 to 2006 for Platinum (Schuster et al. 2006).

1. This document is ENY-735 (IN695), a publication of the Entomology and Nematology Department, Florida Cooperative Extension Service, Institute of Food and Agricultural Sciences, University of Florida. Publication date: March 2007. Please visit the EDIS Website at http://edis.ifas.ufl.edu.

2. David J. Schuster, professor, Entomology and Neamtology Department, Gulf Coast Research and Education Center, Wimauma; Philip A. Stansly, professor, Entomology and Neamtology Department, Southwest Florida Research and Education Center, Immokalee; Jane E. Polston, professor, Plant Pathology Department, Gainesville; Phyllis R. Gilreath, extension agent IV, Manatee County Extension Service, Palmetto; and Eugene McAvoy, extension agent III, Hendry County Extension Service, Labelle, Florida Cooperative Extension Service, Institute of Food and Agricultural Sciences, University of Florida, Gainesville, FL 32611.

The Institute of Food and Agricultural Sciences (IFAS) is an Equal Opportunity Institution authorized to provide research, educational information and other services only to individuals and institutions that function with non-discrimination with respect to race, creed, color, religion, age, disability, sex, sexual orientation, marital status, national origin, political opinions or affiliations. U.S. Department of Agriculture, Cooperative Extension Service, University of Florida, IFAS, Florida A. \& M. University Cooperative Extension Program, and Boards of County Commissioners Cooperating. Millie Ferrer, Interim Dean 
Biotype Q of the sweetpotato whitefly is the most prevalent biotype in the Mediterranean region and has plagued greenhouse-grown crops in southern Spain for years. This biotype is resistant to many of the commonly used insecticides for managing whiteflies, including the pyrethroids, neonicotinoids, pymetrozine and insect growth regulators (Courier and Knack) and was recently discovered in Arizona (Dennehy et al. 2005). Furthermore, resistance in biotype $\mathrm{Q}$ is more stable than that in biotype $\mathrm{B}$, i.e. resistance appears not to diminish over time. Biotype $\mathrm{Q}$ has now been found in greenhouses and nurseries in 22 states including Florida. Although the biotype has not been detected in the field, it represents a new threat to vegetables and other crops in Florida. Strict adherence to management guidelines, especially those dealing with crop hygiene and cultural controls, is important in preventing or at least delaying the establishment of biotype Q in the field as well in reducing selection pressure for resistance to the neonicotinoids and other insecticides.

A Resistance Management Working Group was formed in 2003 to promote resistance management on a regional basis. The group modified previous resistance management recommendations (Schuster and Thompson 2001, 2004; Schuster et al. 2002, 2003) and met with growers to encourage their adoption. The Working Group consisted of University of Florida research and extension personnel, representatives of the chemical companies marketing neonicotinoid insecticides, representatives of commodity organizations, and commercial scouts. Because of the threat of biotype Q and decreased insecticide susceptibility, the group was expanded and met in May, 2006 to discuss and revise the whitefly and resistance management recommendations. The recommendations include field hygiene and cultural practices which should be considered a high priority and should be included as an integral part of the overall strategy for managing whitefly populations, TYLCV incidence, and insecticide resistance. These practices will help reduce the onset of the initial infestation of whitefly and lower the initial infestation level during the cropping period, thus reducing insecticide use and selection pressure for insecticide resistance development. Also included are insecticide use recommendations which help to improve whitefly and resistance management. It is recognized that the insecticide use recommendations will not be successful in delaying or reducing insecticide resistance without strict adherence to recommended cultural practices.

\section{Recommendations}

\section{A. Crop Hygiene.}

Field hygiene should be a high priority and should be included as an integral part of the overall strategy for managing whitefly populations, TYLCV incidence, and insecticide resistance. These practices will help reduce the onset of the initial infestation of whitefly, regardless of biotype, and lower the initial infestation level during the cropping period.

\section{Establish a minimum 2 month crop free period during the summer, preferably from mid-June to mid-August.}

\section{Disrupt the virus-whitefly cycle in winter by creating a break in time and/or space between fall and spring crops, especially tomato.}

\section{Destroy the crop quickly and thoroughly, killing whiteflies and preventing re-growth.}

a. Promptly and efficiently destroy all vegetable crops within 5 days of final

harvest to decrease whitefly numbers and sources of plant begomoviruses like TYLCV.

b. Use a contact desiccant ("burn down") herbicide in conjunction with a heavy application of oil (not less than $3 \%$ emulsion) and a non-ionic adjuvant to destroy crop plants and to kill whiteflies quickly.

c. Time burn down sprays to avoid crop destruction during windy periods, especially when prevailing winds are blowing whiteflies toward adjacent plantings. 
d. Destroy crops block by block as harvest is completed rather than waiting and destroying the entire field at one time.

\section{B. Other Cultural Control Practices.}

Reduce overall whitefly populations, regardless of biotype, and avoid introducing whiteflies and TYLCV into crops by strictly adhering to correct cultural practices.

\section{Use proper pre-planting practices.}

a. Plant whitefly and virus-free transplants.

1) Do not grow vegetable transplants and vegetatively propagated ornamental plants (i.e. hibiscus, poinsettia, etc.) at the same location, especially if bringing in plant materials from other areas of the US or outside the US.

2) Isolate vegetable transplants and ornamental plants if both are produced in the same location.

3) Do not work with or manipulate vegetable transplants and ornamental plants at the same time.

4) Practice worker isolation between vegetable transplants and ornamental crops.

5) Avoid yellow clothing or utensils as these attract whitefly adults.

6) Cover all vents and other openings with whitefly resistant screening $(0.25 \times 0.8 \mathrm{~mm}$ openings or less for passive ventilation, less for forced air ventilation). Use double doors with positive pressure. Cover roofs with UV absorbing films.

b. Delay planting new fall crops as long as possible. c. Do not plant new crops near or adjacent to old, infested crops.

d. Use determinant varieties of grape tomatoes to avoid extended crop season.

e. Use TYLCV resistant tomato cultivars (see additional information below for list) where possible and appropriate, especially during historically critical periods of virus pressure. Whitefly control must continue even with use of TYLCV resistant cultivars because these cultivars can carry the virus.

f. Use TYLCV resistant pepper cultivars (see additional information below for a source of a list) when growing pepper and tomato in close proximity.

g. Use ultraviolet light reflective (aluminum) mulch on plantings that growers find are historically most commonly infested with whiteflies and infected with TYLCV.

\section{Use proper post-planting practices.}

a. Apply an effective insecticide to kill whitefly adults prior to cultural manipulations such as pruning, tying, etc.

b. Rogue tomato plants with symptoms of TYLCV at least until second tie. Plants should be treated for whitefly adults prior to roguing and, if nymphs are present, should be removed from the field, preferably in plastic bags, and disposed of as far from production fields as possible.

c. Manage weeds within crops to minimize interference with spraying and to eliminate alternative whitefly and virus host plants.

d. Dispose of cull tomatoes as far from production fields as possible. If deposited in pastures, fruit should be spread instead of dumped in a large pile to encourage consumption by cattle. The fields should then be monitored for germination of 
tomato seedlings, which should be controlled by mowing or with herbicides if present.

e. Avoid u-pick or pin-hooking operations unless effective whitefly control measures are continued.

f. Destroy old crops within 5 days after harvest, destroy whitefly infested abandoned crops, and control volunteer plants with a desiccant herbicide and oil.

g. Plant non-host cover crops such as Sudex to discourage weeds and volunteer crop plants from growing and being infested by whiteflies.

\section{Insecticidal Control Practices.}

\section{Delay resistance to neonicotinoid and} other insecticides by using a proper whitefly insecticide program. Follow the label!

a. On transplants in the production facility, do not use a neonicotinoid insecticide if biotype $\mathrm{Q}$ is present. If biotype $\mathrm{B}$ is present, apply a neonicotinoid one time 7-10 days before shipping. Use products in other chemical classes, including Fulfill, soap, etc. before this time.

b. Use neonicotinoids in the field only during the first six weeks of the crop, thus leaving a neonicotinoid-free period at the end of the crop.

c. As control of whitefly nymphs diminishes following soil drenches of the neonicotinoid insecticide or after more than six weeks following transplanting, use rotations of insecticides of other chemical classes including insecticides effective against biotype Q. Consult the Cooperative Extension Service for the latest recommendations.

d. Use selective rather than broad-spectrum control products where possible to conserve natural enemies and enhance biological control. e. Do not apply insecticides on weeds on field perimeters. These could kill whitefly natural enemies and, thus, interfere with biological control, as well as select for biotype Q, if present, which is more resistant to many insecticides than biotype B.

\section{Soil applications of neonicotinoid} insecticides for whitefly control.

a. For best control, use a neonicotinoid as a soil drench at transplanting, preferably in the transplant water.

b. Soil applications of neonicotinoids through the drip irrigation system are inefficient and not recommended.

c. Do not use split applications of soil drenches of neonicotinoid insecticides (i.e. do not apply at transplanting and then again later).

\section{Foliar applications of neonicotinoid insecticides for whitefly control.}

a. Foliar applications, if used instead of or in addition to soil drenches at transplanting, should be restricted to the first 6 weeks after transplanting. Do not exceed the maximum active ingredient per season according to the label.

b. Follow scouting recommendations when using a foliar neonicotinoid insecticide program. Rotate to non-neonicotinoid insecticide classes after the first 6 weeks and do not use any neonicotinoid class insecticides for the remaining cropping period.

\section{Do unto your neighbor as you would have him do unto you.}

\section{Look out for your neighbor's welfare.}

This may be a strange or unwelcome concept in the highly competitive vegetable industry but it is in your best interest to do just that. Growers need to remember that, should the whiteflies 
develop full-blown resistance to

insecticides, especially the

neonicotinoids, it's not just the other guy

that will be hurt-everybody will feel the

pain! This is why the Resistance

Management Working Group has focused

on encouraging region-wide cooperation in this effort.

\section{Know what is going on in the neighbor's fields.}

Growers should try to keep abreast of operations in upwind fields, especially harvesting and crop destruction, which both disturb the foliage and cause whitefly adults to fly. Now that peppers have been added to the list of TYLCV hosts, tomato growers will need to keep in touch with events in that crop as well.

Efficacy information generated by Florida researchers for insecticides used against biotype B in Florida are summarized and tabulated in Table 1. Known resistance of both biotypes B and Q also are included as are the Insecticide Resistance Action Committee (IRAC) classification and comments for each compound. This information should be helpful to growers, scouts and consultants in formulating insecticide programs.

\section{Additional Information}

IRAC (Insecticide Resistance Action Committee) provides additional information on general resistance management and on resistance classification of specific insecticides at its website: http://www.irac-online.org.

More suggestions for breaking the whitefly/ TYLCV cycle and a list of TYLCV resistant pepper cultivars can be found in articles by Dr. Jane Polston in the 2002 and 2003 Proceedings of the Florida Tomato Institute: http://swfrec.ifas.ufl.edu/ veghort/docs/tom_inst_2002_091202.pdf and http://gcrec.ifas.ufl.edu/TOMATO\%202003.pdf, respectively.

TYLCV resistant tomato cultivars can be found in an article by Dr. Jay Scott in the 2004 Florida
Tomato Institute Proceedings:

http://gcrec.ifas.ufl.edu/Tomato Optimized.pdf; and in an article by Drs. Kent Cushman and Phil Stansly in the 2006 Florida Tomato Institute Proceedings: http://gcrec.ifas.ufl.edu/Tomato_2006.pdf.

\section{References Cited}

Elbert, A. and R. Nauen. 2000. Resistance in Bemisia tabaci (Homoptera: Aleyrodiae) to insecticides in southern Spain with special reference to neonicotinoids. Pest Management Sci. 56:60-64.

Dennehy, T. J., B. A. DeGain, V. S. Harpold, J. K. Brown, S. Morin and J. A. Fabrick. 2005. New challenges to management of whitefly resistance to insecticides in Arizona. Univ. Ariz., College of Agric., Veg. Rpt. http://mrec.ifas.ufl.edu/lso/ DOCUMENTS/Dennehy\%20et\%20al\%2005\% 20WF\%20Report--Extension.pdf.

Schuster, D. J. and S. Thompson. 2001. Monitoring susceptibility of the silverleaf whitefly to imidacloprid, pp. 16-18. In P. Gilreath and C. S. Vavrina [eds.], 2001 Fla. Tomato Institute Proc., Univ. Fla., Gainesville, PRO 518.

Schuster, D. J. and S. Thompson. 2004. Silverleaf whitefly resistance management update, pp. 19-25. In P. Gilreath and W. H. Stall [eds.], Fla. Tomato Institute Proc., Univ. Fla., Gainesville, PRO 521.

Schuster, D. J., S. Thompson, P. A. Stansly and J. Conner. 2002. Update on insecticides for whitefly and leafminer control, pp. 51-60. In P. Gilreath and C. S. Vavrina [eds.], 2002 Fla. Tomato Institute Proc., Univ. Fla., PRO 519.

Schuster, D. J., S. Thompson and P. R. Gilreath. 2003. Whats up with all these whiteflies?, pp. 12-19. In P. Gilreath and W. H. Stall [eds.], Fla. Tomato Institute Proc., Univ. Fla., PRO 520.

Schuster, D. J., R. Mann and P. R. Gilreath. 2006. Whitefly resistance update and proposed mandated burn down rule, pp. 24-28. In P. Gilreath and K. Cushman [eds.], 2006 Fla. Tomato Institute Proc., Univ. Fla., PRO 523. 


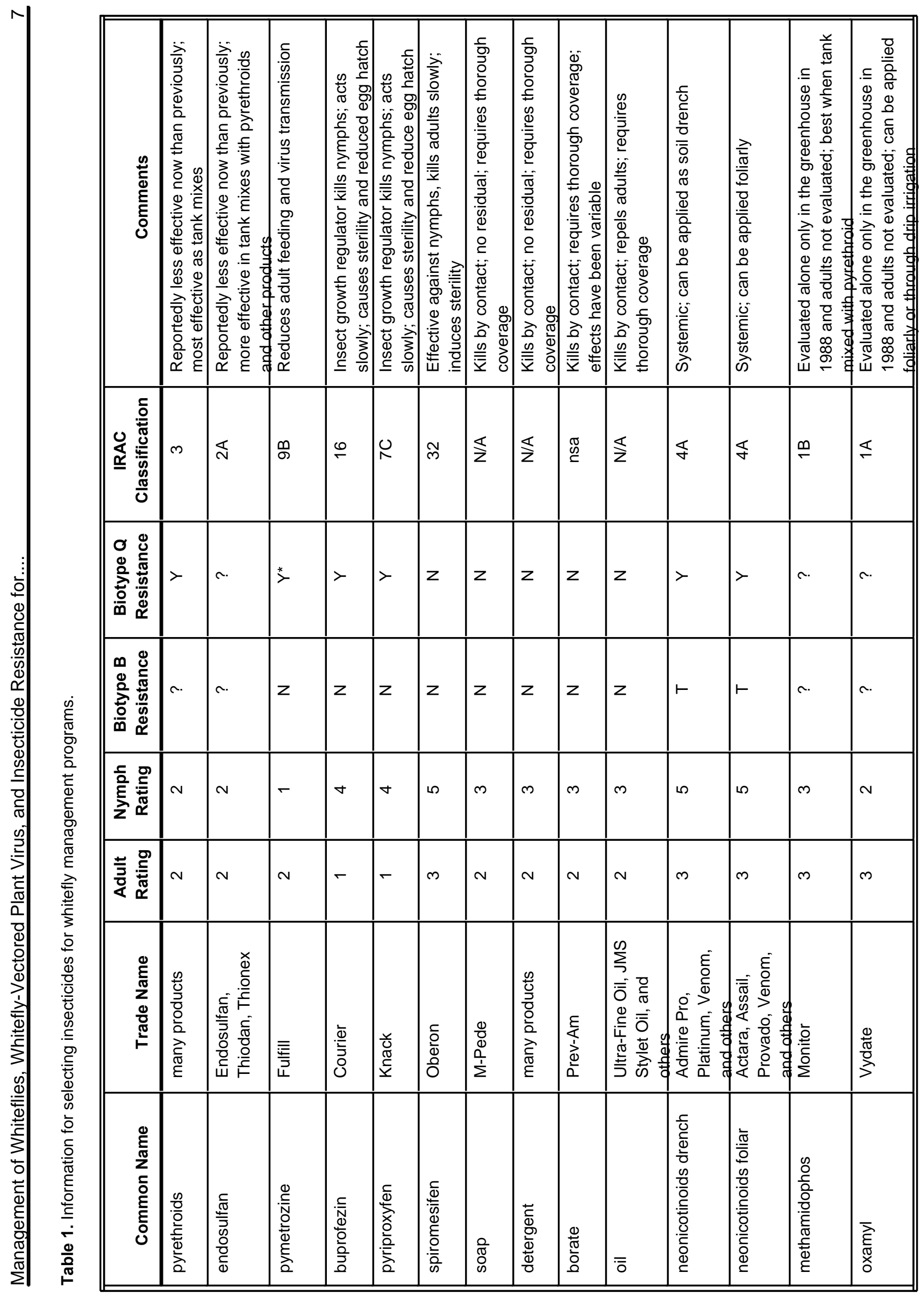




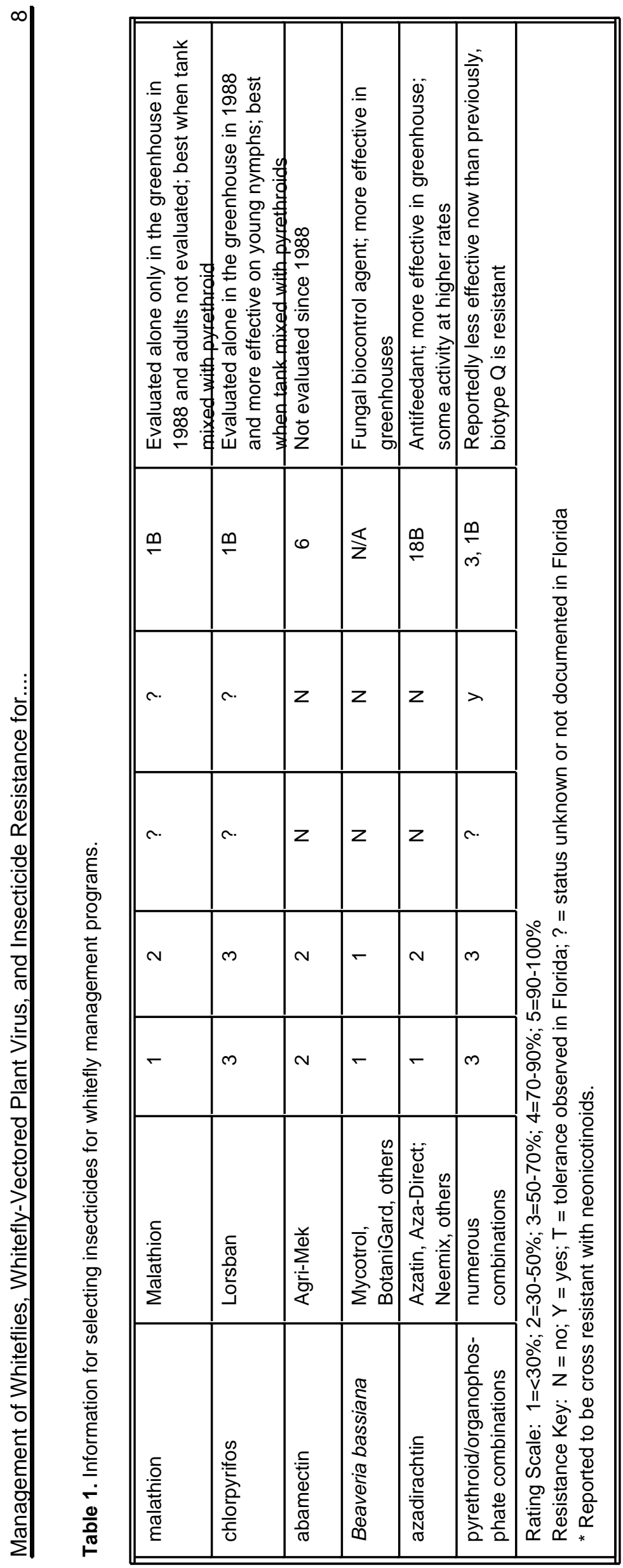

